\title{
Plagiarism in scientific publications
}

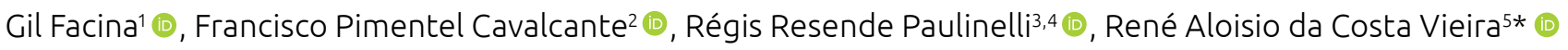

\section{ABSTRACT}

Plagiarism in scientific publications is a topic of fundamental importance and rarely addressed in the literature. It is associated with ethical issues that go beyond research itself, a fact that values the discussion on the topic. The concept, the main types of plagiarism, ethical relationships, preventive methodologies aiming to minimize their occurrence, diagnostic methodologies, and potential penalties involved are discussed. Every researcher and team involved in publishing articles should be aware of the importance and relevance of not plagiarizing, since being cautious about it is essential to build a solid curriculum on the part of the researcher, and credibility on the part of scientific journals.

KEYWORDS: plagiarism; scientific misconduct; codes of ethics; publications.

\section{PLAGIARISM IN SCIENTIFIC PUBLICATIONS}

In the dictionary, the term plagiarism implies the act or effect of plagiarizing, copying, imitating, or reproducing. ${ }^{1}$ From a legal point of view, stealing an idea is like stealing someone's property. ${ }^{2}$ Scientific journals have been increasingly concerned in this regard, considering that although authors transfer their copyright to journals, they maintain responsibility for the written material, and the occurrence of plagiarism may imply loss of authors' reputation and/or scientific journal. When evaluating the term plagiarism on Medical Subject Headings (MeSH), less than two thousand references are observed in PubMed, ${ }^{3}$ and, when associated with the term Brazil or Brazilian, there are less than 25 publications, a fact that suggests the need for discussing this subject, still incipient in Brazil, in order to address the concepts involved, preventive measures, and evaluation methodologies.

Today, when writing a scientific article, authorship is often divided due to the difficulty of carrying out innovative and complex research, and many authors, in their study groups, come to believe in the reputation of their team, which can be compromised if one of the collaborators plagiarizes. As to younger researchers, there is a desire to publish, unaware that plagiarism shares conceptual and philosophical similarities with cheating on an exam. Likewise, for senior researchers, publication in indexed journals is a fundamental factor in their academic life in research institutions. Senior researchers and scientific journals are responsible for preserving the image they build over time.

Ethics is not only associated with the submission of the study to a committee for conducting research, but it is also present in the preparation of the text, in which the practice of plagiarism poses ethical questions. ${ }^{4}$ Thus, scientific journals request that authors take responsibility for the originality of the publication, obtaining their signature or consent through e-mail.

Public retraction associated with publications may be due to misconduct, gross errors or fraud, with plagiarism being the main factor. ${ }^{5}$ From a writing point of view, plagiarism can be considered substantially copying and pasting, making a literal copy of a text, paraphrasing (placing words in the middle of copied text), or recycling a text (self-plagiarism). ${ }^{6}$ We can also divide plagiarism into four main forms: ${ }^{7}$

- Form: it represents the copy of sentences or sentences taken from another text;

- Content: uses previous data, without the given express authorization of the author, such as definitions, figures, and images;

\footnotetext{
'Universidade Federal de São Paulo - São Paulo (SP), Brazil.

${ }^{2}$ Hospital Geral de Fortaleza - Fortaleza (CE), Brazil.

${ }^{3}$ Hospital Araújo Jorge, Associação de Combate ao Câncer de Goiás - Goiânia (GO), Brazil.

${ }^{4}$ Hospital das Clínicas da Universidade Federal de Goiás - Goiânia (GO), Brazil.

${ }^{5}$ Hospital do Câncer de Muriaé, Fundação Cristiano Varella - Muriaé (MG), Brazil.

*Corresponding author: reneacv@terra.com.br

Conflict of interests: nothing to declare.

Received on: 08/05/2020. Accepted on: 08/07/2020
} 
- Concept: it consists of the appropriation of research methods, experimental procedures, or argued structures. Authors must use their own words and ideas and be careful, and remember to cite the authors who presented similar concepts;

- Self-plagiarism: authors, as they carry out research in the line, transfer copyright to journals when publishing a study. Therefore, care should be taken when preparing their texts. When many works are published on the same project, authors must try not to repeat the narration or present the same information. The limits are not well defined in the literature, but this situation urges for care and attention. ${ }^{8}$

Some measures are suggested to reduce plagiarism, among them: the education of researchers on the subject; the institution of policies for revising the material by undergraduate and graduate programs, and scientific journals; the monitoring of content and the creation of internal penalty mechanisms, such as the refusal to publish in scientific journals and even the suspension of research programs. ${ }^{9,10}$

For the authors, one of the ways to avoid plagiarism may be to organize ideas previously, before the writing itself begins. Thus, before starting text elaboration, a proper bibliographic review is suggested, in which different concepts are marked in the references, and, later, the grouping of references into concepts is performed. Junior researchers are advised to avoid the use of textbooks, using these only to understand the subject, which should be followed by a literature review. The selection of review articles, systematic reviews, and meta-analyzes greatly facilitates problem understanding, but writing must be based on the understanding and presentation of the concepts and ideas, followed by references that support the statements. The use of references from textbooks is not recommended, preferring the use of original articles published in recent years. After understanding the topic and the potential concepts to be presented, these should be organized into paragraphs to create a linearity of ideas and justify the introduction and discussion. The results should be compared to previous publications, highlighting the potential differences between the studies, a fact that values the publication. The task is not easy and requires time, effort, dedication, and teamwork. Researchers are not born ready, they learn from their mistakes.

Reading and rereading, care with the content and reflection on it qualify the material presented. The text must be linear, and multiple adjustments are often necessary until the final version is reached. The journals request the description of the individual participation of each author in the construction of the text, and the review of the text by the entire team is required, a fact that aims to minimize problems related to the understanding and to maximize the quality of the material. Another point to be discussed is the need to use a table or figure, or part of them, which were previously published. The simple citation of the source does not authorize researchers to use them. Granting of rights to use by the author or the scientific journal is needed, along with the citation of the source. In the case of systematic reviews and meta-analyzes, this is not necessary, since raw data will be used and the author who collected such information will be cited.

There is a range of plagiarism detection software, such as Turnitin $^{\circledR}$, Ephorus ${ }^{\circledR}$, WCopyfind ${ }^{\circledR}$, as well as websites that carry out this assessment, such as iThenticate ${ }^{\circledR}$ (www.ithenticate.com), JPlag ${ }^{\circledR}$ (www.jplag.de/), Plagiarism Combat ${ }^{\circledR}$ (http:// www.plagiarismcombat.com), Viper ${ }^{\circledR}$ (https://www.scanmyessay.com), checkForm ${ }^{\circledR}$, and Plagiarism ${ }^{\circledR}$ (https://www.checkforplagiarism.net) ${ }^{11,12}$.

When analyzing the text in a plagiarism detector program, they evaluate similarities between publications, as well as between published references, displaying phrases, references and, finally, a percentage of similarities. Authors should be careful when writing their text to avoid using few sources and respective references, and reviewers should be careful when evaluating percentages and crossing data. It is up to the editor to evaluate the content presented and observe the similarities in the phrases, ideas, and references.

These software analyze similarities between phrases, paragraphs, and articles, which are identified by colors, and, finally, present partial and total similarity scores that will allow the reviewers a more careful analysis. There is no limit defined as acceptable for plagiarism. There are several indices in the literature, such as 5, 10, and 20\%. ${ }^{10,13}$ A study that evaluated the potential cutoff for considering plagiarism, when using the iThenticate $^{\circledR}$ software, found the $15 \%$ similarity limit to be acceptable. ${ }^{14}$ However, currently, there is a zero tolerance policy in international and national journals.

Every researcher and their team must be aware of the importance and relevance of not plagiarizing, thus allowing a climate of trust between authors and editors, a fact that motivated the present discussion. Measures and care related to plagiarism are fundamental in building a solid curriculum on the part of the researcher, and credibility on the part of scientific journals.

\section{AUTHORS' CONTRIBUTION}

G.F.: Conceptualization, Data curation, Formal analysis, Project administration, Writing - original draft.

F.P.C.: Conceptualization, Data curation, Formal analysis, Writing - original draft.

R.R.P.: Conceptualization, Data curation, Formal analysis, Writing - original draft.

R.A.C.V.: Conceptualization, Data curation, Formal analysis, Project administration, Writing - original draft. 


\section{REFERENCES}

1. Michaelis. Dicionário Brasileiro da língua Portuguesa [Internet]. [cited on Aug 4, 2020]. Available at: https:// michaelis.uol.com.br/moderno-portugues/busca/portuguesbrasileiro/Plágio/

2. JusBrasil. Plágio: quando a cópia vira crime [Internet]. JusBrasil; 2012 [cited on Aug 4, 2020]. Available at https://stj.jusbrasil.com. br/noticias/3174944/plagio-quando-a-copia-vira-crime

3. PubMed [Internet]. Bethesda: National Library of Medicine; c2020 [cited on July 31, 2020]. Available from: https://pubmed. ncbi.nlm.nih.gov

4. Benos DJ, Fabres J, Farmer J, Gutierrez JP, Hennessy K, Kosek D, et al. Ethics and scientific publication. Adv Physiol Educ. 2005;29(2):59-74. https://doi.org/10.1152/advan.00056.2004

5. Stavale R, Ferreira GI, Galvão JAM, Zicker F, Novaes M, Oliveira $\mathrm{CM}$, et al. Research misconduct in health and life sciences research: A systematic review of retracted literature from Brazilian institutions. PLoS One. 2019;14(4):e0214272. https:// doi.org/10.1371/journal.pone.0214272

6. Debnath J. Plagiarism: A silent epidemic in scientific writing Reasons, recognition and remedies. Med J Armed Forces India. 2016;72(2):164-7. https://doi.org/10.1016/j.mjafi.2016.03.010

7. Chamon W, Dantas PE. What is plagiarism after all? Arq Bras Oftalmol. 2016;79(2):V-VI. http://dx.doi.org/10.5935/00042749.20160021
8. MacDermid JC. Self-plagiarism is not easily defined, but should be avoided. J Hand Ther. 2018;31(4):427-8. https://doi. org/10.1016/j.jht.2018.10.001

9. Guraya SY, Guraya SS. The confounding factors leading to plagiarism in academic writing and some suggested remedies: A systematic review. J Pak Med Assoc. 2017;67(5):767-72.

10. Kadam D. Academic integrity and plagiarism: The new regulations in India. Indian J Plast Surg. 2018;51(2):109-10. https://dx.doi.org/10.4103\%2Fijps.IJPS_208_18

11. Araújo ERO. The plagiarism in scientific research of higher education. RCA. 2017;2(1):93-107.

12. Kumar PM, Priya NS, Musalaiah S, Nagasree M. Knowing and avoiding plagiarism during scientific writing. Ann Med Health Sci Res. 2014;4(Suppl. 3):S193-8. https://dx.doi. org/10.4103\%2F2141-9248.141957

13. Memon AR. Similarity and Plagiarism in Scholarly Journal Submissions: Bringing Clarity to the Concept for Authors, Reviewers and Editors. J Korean Med Sci. 2020;35(27):e217. https://dx.doi.org/10.3346\%2Fjkms.2020.35.e217

14. Higgins JR, Lin FC, Evans JP. Plagiarism in submitted manuscripts: incidence, characteristics and optimization of screening-case study in a major specialty medical journal. Res Integr Peer Rev. 2016;1:13. https://doi.org/10.1186/s41073-016$0021-8$ 